\title{
GROUNDWATER MANAGEMENT FOR THE ENHANCEMENT OF THE URBAN FABRIC IN HISTORIC CAIRO.
}

\author{
Prof. Dr. Alaa El-Habashi \\ Department of Architectural Engineering \\ University of Menoufia \\ Shebien El-Kom, EL-Menoufia, Egypt \\ Alaa.elhabashi@gmail.com
}

\author{
Ebtesam Said Ahmed Shelf \\ Department of Architectural Engineering \\ University of Menoufia \\ Shebien El-Kom, Menoufia, Egypt \\ eng.ebtisamsaid@gmail.com
}

\begin{abstract}
:
The rise of groundwater in Cairo during the last two decades is threating the safety and durability of existing buildings. One of the major reasons of this was filling most of the open water resources in Historic Cairo started from the first half of the 19th century, such as birkat al-Azbakkiyya, birkat al-Fil and al-Khalij al-Masri canal. The urban transformation created by filling most of those water resources was the first step for the substantial changes in the built fabric of the historical city, and marked climatic, environmental, and social changes.

Additional harmful consequence is the continuous unprecedented rise of groundwater that affects the foundations of historic buildings. The rising dampness throughout the built historic fabric contributes in damaging the building systems and accentuates the state of the conservation of many valuable monuments.

This study provides an assessment of water urban features in Historic Cairo prior to their filling and indicates through the survey of selected monuments the groundwater effects on the built fabric. It proposes retrofitting approaches based on the control of the rising groundwater, its collection and profiting from it. The paper investigates the possibility to channelling it in order to fulfil various needed purposes of which: reintegrating water features in selected public spaces to enhance the climatic conditions of the historical city; reusing historic architectural elements that were of particular value in the historic city such as cisterns and water tanks. Those approaches would contribute in the regeneration of the historic city through the improvement of the qualities of the open public spaces, as well as to accentuate and help interpreting some of its outstanding values. The study adopts a qualitative approach to demonstrate suitable models extracted from international examples to be suggested to Historic Cairo.
\end{abstract}

Index Terms - Historic Cairo, Groundwater, Cooling systems, High value monuments, Cisterns.

\section{INTRODUCTION}

This study is about groundwater that is usually threatening the built fabric of Historic Cairo, and how to profit from it to offer means to use it in controlling the climatic conditions of the buildings and in enhancing the urban qualities of selected public spaces. One of the main research approaches is based on the understanding of the historic water existence and management and on relating existing attributes to that water system in the city. In that respect, the research investigates the possibility to improve the open public spaces in the historic city through the possible reintegration and the reusing of some of its historic, but almost forgotten, water features. The aim is to propose means to manage such attributes to reveal and accentuate their historical values, as well as to reuse them in their respective historic fields in ways that would guarantee their preservation and would meanwhile offer chances to enhance the contemporary qualities of the urban fabric. The research objectives can be summarized in the following points:
1. The use of the groundwater in Historic Cairo in controlling the climatic conditions of the existing buildings and selected public spaces.

2. To propose frameworks of water management in the city to reveal and accentuate some historic values, as well as to reuse some of them in their respective fields.

3. To improve the built fabric of Historic Cairo by reviving and possibly reintegrating water resources that were eliminated in the recent past into possible urban vacant spaces in the Historic City. 


\section{HISTORIC WATER MANAGEMENT IN CAIRO AND THE URBAN FABRIC BEFORE THE $19^{\mathrm{TH}}$ CENTURY.}

Social and cultural life in Egypt has been strongly tied to the Nile and its flooding cycles. Egyptians devised an elaborate flood management system consisting of intersecting irrigation canals to face the potentially serious annual flood threat of the Nile. At the time of the flood, the dikes between the river and the canals were cut, and water rushed inland to fill both the canals and lakes instead of being allowed to spread randomly causing damages. As the Nile's overflow was absorbed into this system, a conscious aspect of Cairo's urban fabric integrated an intricate flood management system of canals, lakes, and ponds that encompassed the entire city, as shown in figure 1 . This system not only provided protection against potential flood destruction but also gave the city a unique and ever-changing seasonal character.

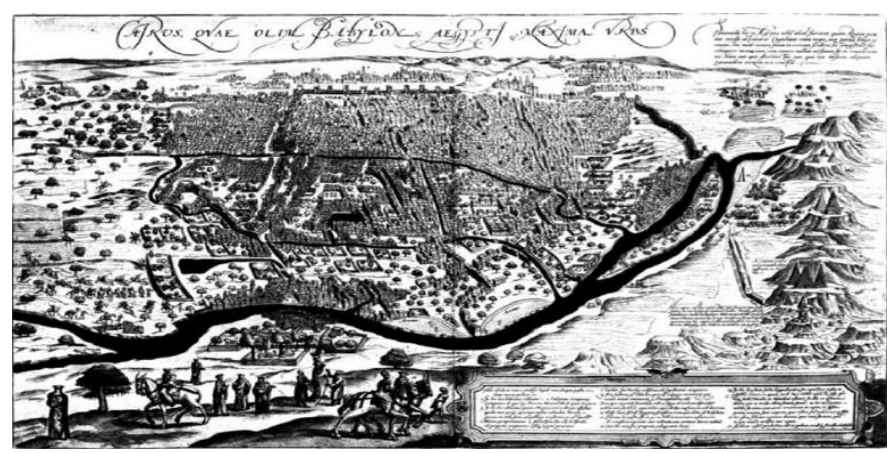

Fig. 1: 1572 Map of Cairo (water resource management before the 19th century) [1].

Flood management system played a prominent role in the social, cultural, and urban character of Cairo and influenced recreation, entertainment, cultural and religious festivities among many other diverse aspects of the City's urban life. The grandest festivities were those that marked the opening of the dykes (qasr al-Khalij or fath al-Khalij), which celebrated the rise of the Nile to 16 cubits at the Nilometer at al-Rawdah and the arrival of the flood in Cairo, as shown in figures 2 and 3. Nothing was more pleasant than a place filled with water during the eight months of the year, while during the remaining months turning into gardens. While the ponds were flooded with water, they were full of boats to entertain the elite families of the society, not to mention the fireworks and concerts during the evenings to amuse the others. A multitude of women were at their windows overlooking the ponds, and the facades of all houses were lit during the evening [1]. (Fig. 4)

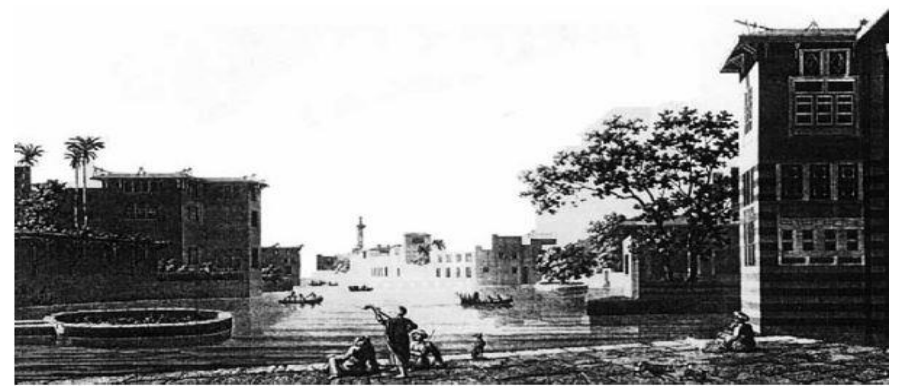

Fig. 2: Entertainment by the shores of Birkat al-Fil [1].

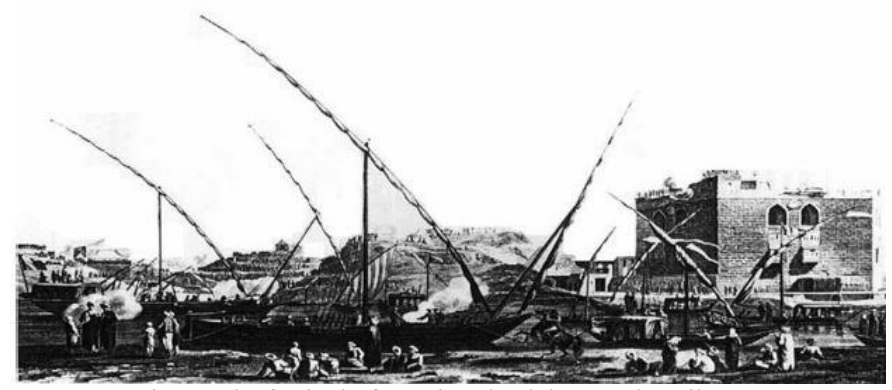

Fig. 3: The festival of opening the dykes on the Nile [1].

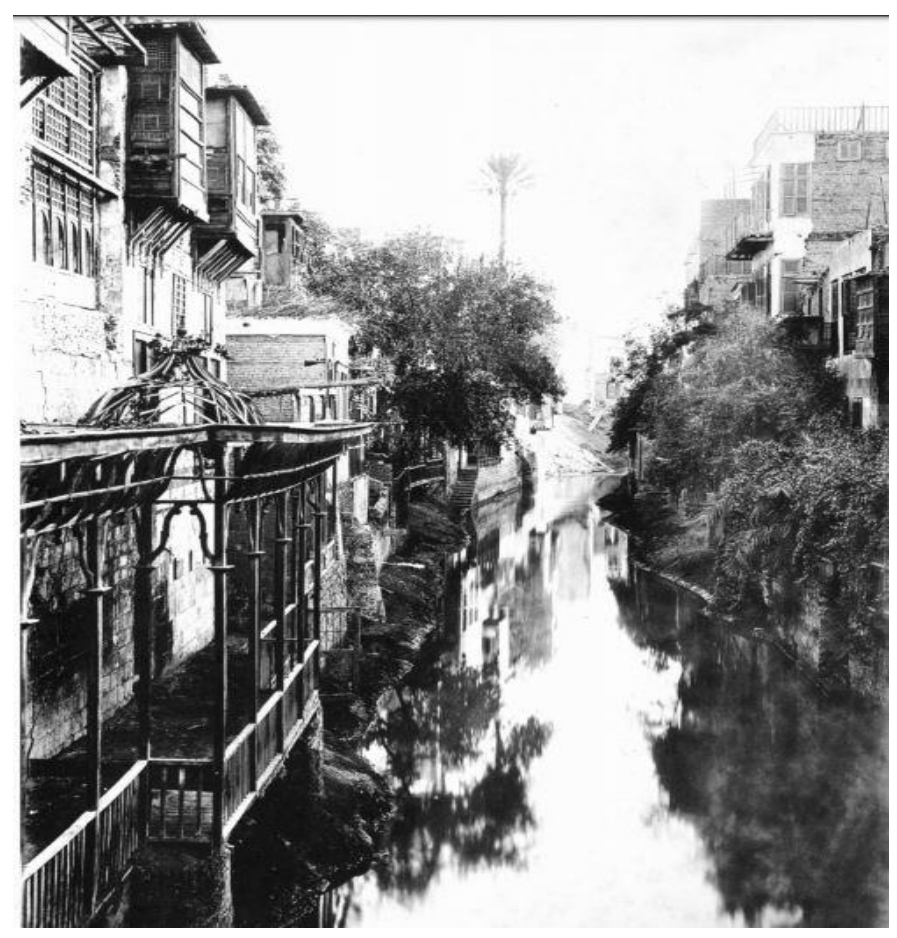

Fig. 4: A panoramic view of al-Khalij al-Masri canal it was dammed in 1896, depicting houses overlooking the bay [2].

\section{19TH CENTURY URBAN TRANSFORMATION}

Cairo's urban form underwent significant structural and functional transformation in the first half of the 19th century during the reign of Mohamad Ali (1805-1848) as shown in figures 5 and 6 . Changes in political and social outlooks under Mohamad Ali resulted in the infill of the city's system of canals, lakes, and ponds as one of his projects that targeted the 
cleaning of Cairo by levelling rubbish mounds and using resultant excess debris for the required filling. Several lakes were either entirely or partially filled, including the two largest: birkat al-Azbakkiyya and birkat al-Fil; a fact that had completely transformed Cairo's urban fabric [1].

During the reign of Khedive Ismail (1879-1863), the filling of ponds and lakes continued to include birkat Abdeen, which is the place of Abdeen's Square now, as well as birkat alAzbakkiyya which was replaced with al- Azbakkiyya Garden. In addition, main squares and streets such as al-Ataba alKhadra Square, Opera Square, Bab al-Hadid Square (Ramses Square), Sulayman Pasha Square (Talaat Harb Pasha Square), Khedive Tawfiq square (al-Tawfiqiya square), al-Antikkhanah square, al-Isma'iliya square (Tahrir Square), al-Qasr al-'Ayni Street, and others replaced other series of filled up ponds and lakes [3].

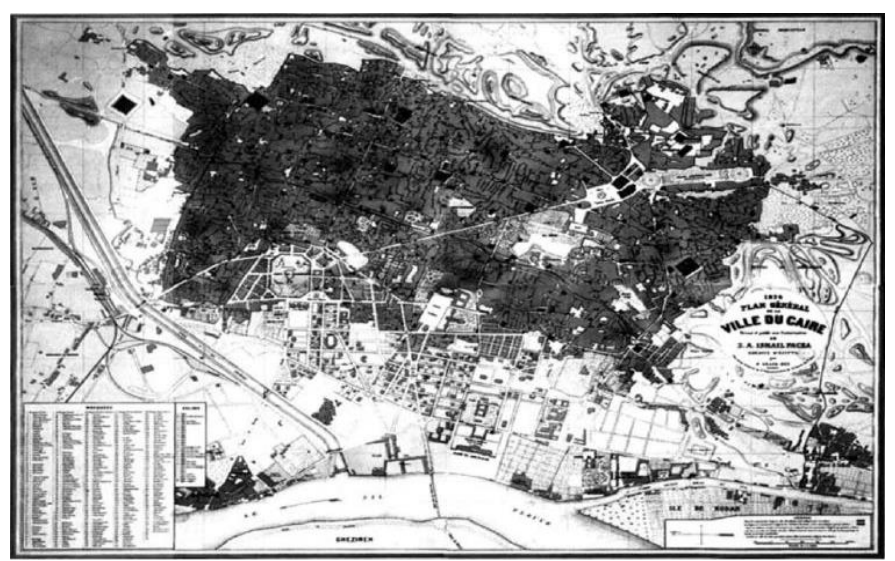

Fig. 5: 1874 plan of Cairo [1]

\section{THE RISING OF GROUNDWATER IN CAIRO}

The groundwater aquifer of Cairo is typically made up of gravel, sand, sandstone, or fractured rock, like limestone; all porous materials carrying such water. The alluvium deposits underlying the whole area of the City contains an aquifer in gravel to sandy sediments with a thickness of up to $60 \mathrm{~m}$. As this aquifer is covered by a thin layer of clay it is characterized as a confined to semiconfined aquifer [4]. (Fig. 9) The quasi impermeable aquifer of Cairo makes all surface rainfalls and/or surface drained water cause the water table to rise, whereas heavy pumping out of groundwater may reversibly cause the water table to fall [5]. (Fig. 7)

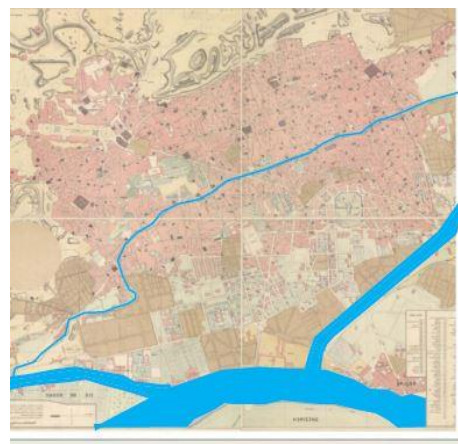

1874 Plan for Cairo.

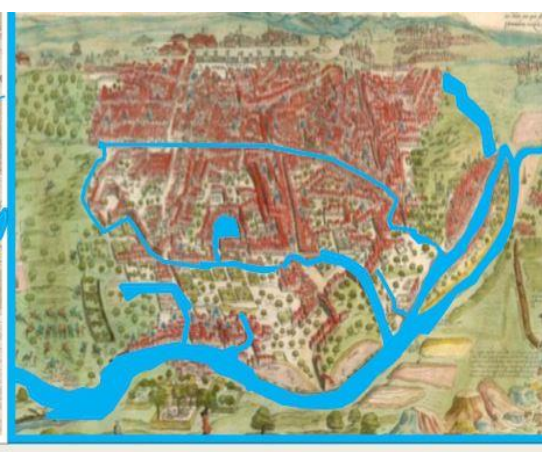

1572 Map of Cairo.
Fig. 6: Comparison between water surfaces before and after filling water resources at the 19th century (authors).

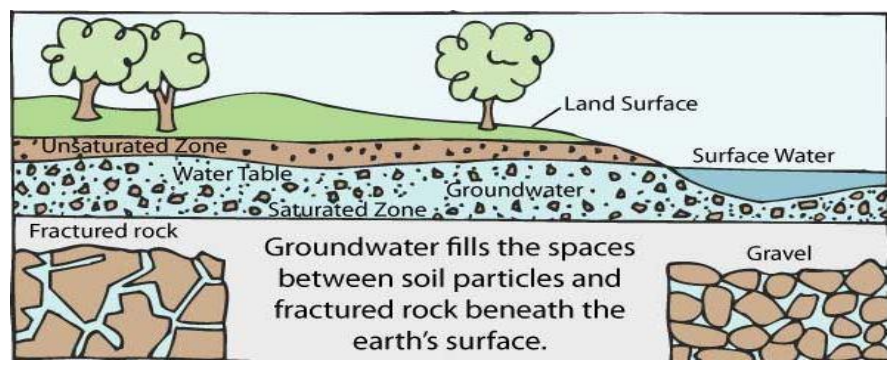

Fig. 7: Generic Profile of Groundwater [5].

According to the 1979 map, the groundwater levels within the City of Cairo-situated on the Eastern bank of the river Nileare in large parts higher than the regulated Nile level which is about 16.5-17 $\mathrm{m}$ above sea level. (Fig. 8) According to that map, the groundwater table reaches 21 meters above sea level at the valley of the Muqattam hill, and 20 meters above sea level in al-Darb al-Ahmar. The Nile River is in fact considered as drainage for the groundwater as its water is below that the groundwater level, especially during its low tide seasons. The more distant from the River Nile the higher the water table is, depending on many parameters among which the permeability of the underground topographical formations. Another criterion that explains the high latitude of the groundwater level is the lack of a lower natural basin, e.g. ponds and lacks, in which it would flow and accumulate. 


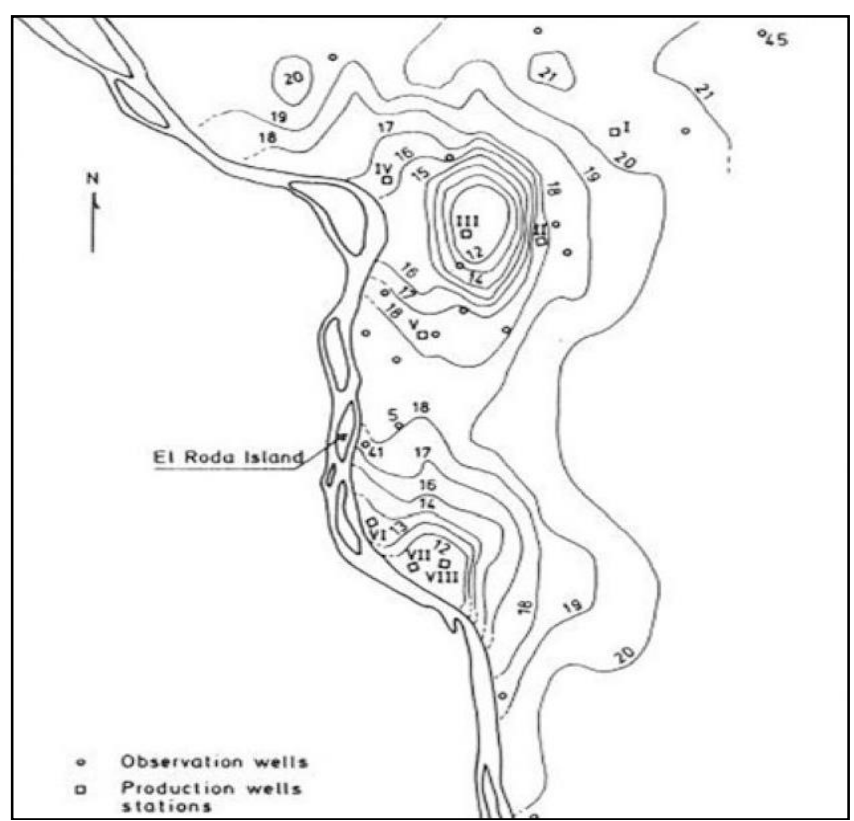

Fig. 8: Map of groundwater levels (water table) for the year 1979 [4].

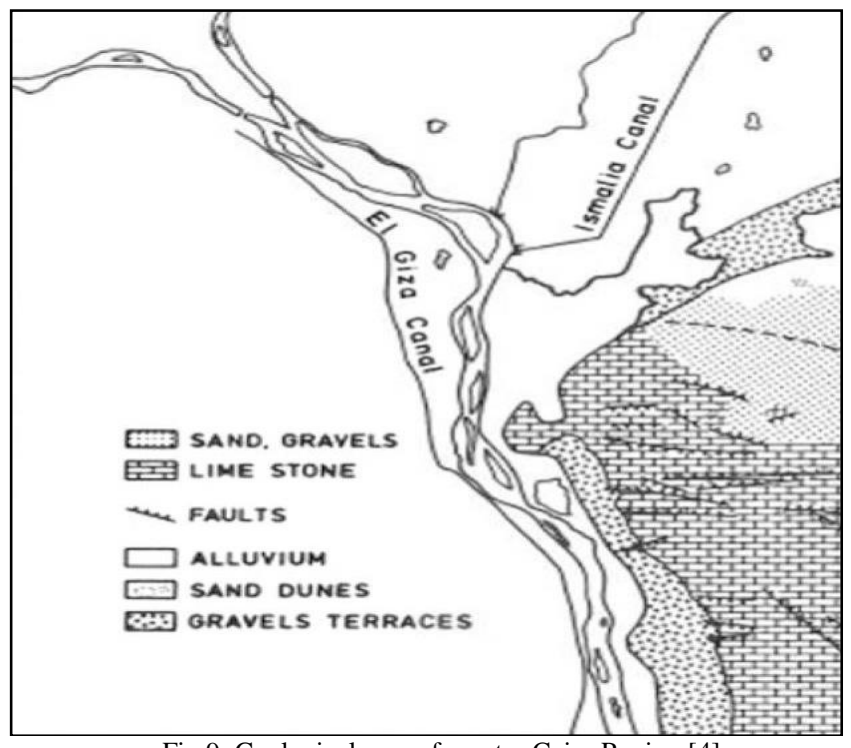

Fig.9: Geological map of greater Cairo Region [4].

The urban transformation and development that took place on the reclaimed lands starting as early as the beginning of the $19^{\text {th }}$ century, marked climatic, environmental, and social modifications. It was reported that the "rise of the groundwater in Cairo during the last two decades is threating the safety and durability of existing buildings" [6]. It had also additional harmful consequences due to the continuous unprecedented rise of groundwater that affects the foundations of historic buildings. The rising dampness throughout the built historic fabric contributes in damaging the building systems and accentuates the state of the conservation of many valuable monuments as shown in figure 10.

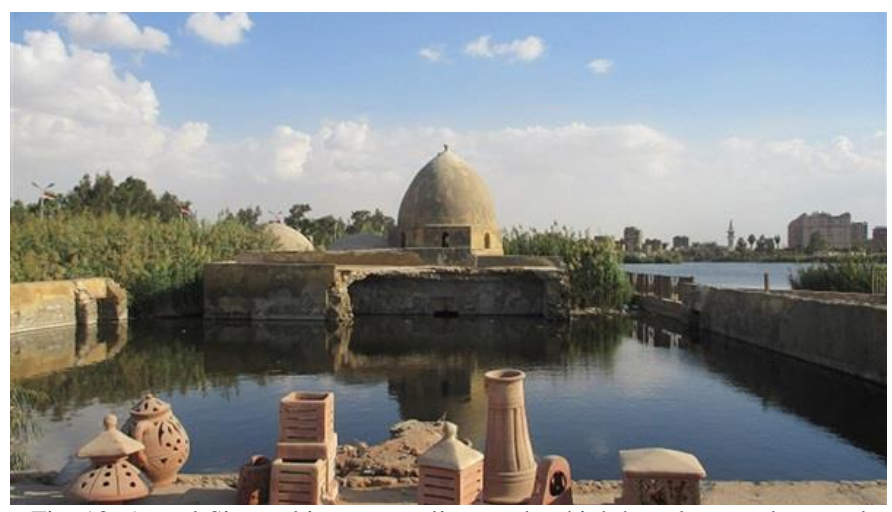

Fig. 10: Ayn al-Sira and its surrounding tomb which has almost submerged the mausoleum of Taba Taba [7].

\section{GROUNDWATER AS AN OPPORTUNITY}

International examples on how to profit from groundwater and use it for some specific benefits to the city can be of a reference to assist Historic Cairo in dealing with one of its problem that threatens its built heritage. This section of the paper presents some trends/approaches of such examples which can be considered and adopted.

The first would be the means to profit from the groundwater low temperature to offer related climatic control devices in buildings and selected public spaces. The example that demonstrates such approach is the systems adopted in the city of London.

The second approach is to restore and rehabilitate historic abandoned water features which are no longer in use to act as groundwater collection points and use them for various purposes. These rehabilitated historic elements can either be considered as a water tank that supplies cooling systems explained in the first approach or else to be used as heritage destination to activate cultural tourism. The second purpose is exemplified here in the case of the Basilica cistern of Istanbul. The latter approach not only lessens the problem of groundwater but also helps in accentuating the historical values of water features that were doomed to extinction.

The third approach is the possibility to use groundwater to surface it for the improvement of the open public spaces in the historic city through the possible reintegration of some of the water features. The city of Utrecht in the Netherlands presents a good example in that domain.

\subsection{Groundwater Cooling Systems in London}

Cooling using the aquifer (groundwater) is a low-technology approach adopted by architects, engineers, and building operators to reduce the use of air conditioning which consequently helps in reducing the environmental impact of the UK building stock. The principle of the system requires the presence of an aquifer from which water can be extracted via boreholes. Cold groundwater is then subtracted from one part of the aquifer (the 'cold' well) at $\left(6-12{ }^{\circ} \mathrm{C}\right)$, depending on the aquifer and its location. It would then be used for cooling 
through fan-coil units. The resultant water that lost its coolness is then recharged into the aquifer at its 'hot' well. When the installations were in areas where the water table is rising, a second borehole is not a requirement. This is the case of the London as the used water is either flushed into the River Thames or drained into the greywater system. (Fig. 11)

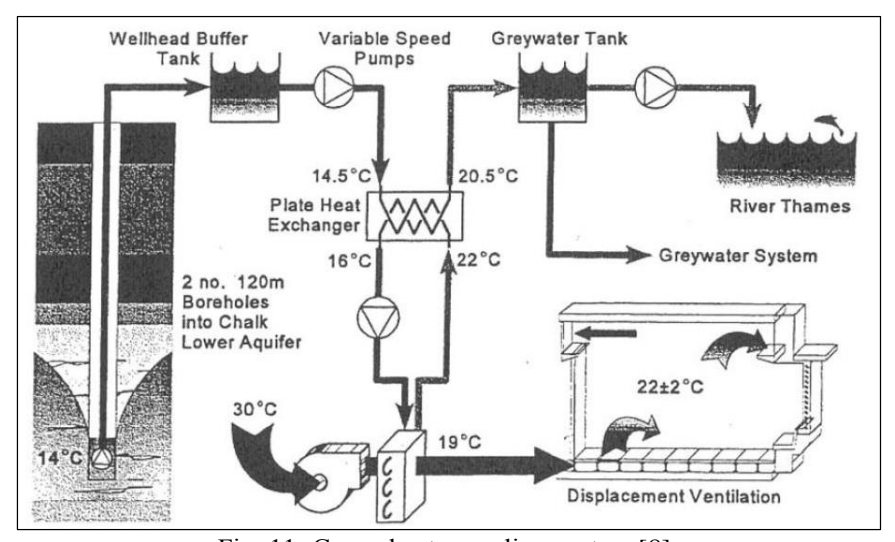

Fig. 11: Groundwater cooling system [8].

There were some issues which affected the exploitation of the groundwater cooling system in London such as the geographical area of the chalk aquifer beneath the city, see fig.12. This chalk aquifer surrounds the majority of the London including its urban development and its suburbs. It is covered with impermeable clay layer preventing the water table rising in the City bursting through. Due to the reduction in groundwater subtraction since the mid-1960s, the groundwater levels in London had increased by as much as $3 \mathrm{~m}$ per year in the 1990s and made the London clay saturated to the degree that it would have affected the stability of certain building foundations. The rising of the groundwater table beneath London was quickly tackled by regarding it as an available resource for potable and non-potable purposes [8]. One of the approaches adopted was to encourage the use of such water in feeding the cooling systems described above; an approach that boosted so many associated manufacturing and businesses including the fabrication of various types of indoor and outdoor public cooling radiators. The case of 2002 London City hall designed by Foster and Partners was an icon in that domain. The refrigeration was avoided, and, instead, cold groundwater was used to air condition the building. The water is extracted from the aquifer below the building via two specially drilled boreholes at a depth of $100 \mathrm{~m}$, and is filtered and pumped at a temperature of about $13{ }^{\circ} \mathrm{C}$. The water is also used in toilets and for irrigation, saving on mains water. After the water has been used, it is discharged into a sewer at a temperature of about $22{ }^{\circ} \mathrm{C}$ [9]. (Fig. 13)
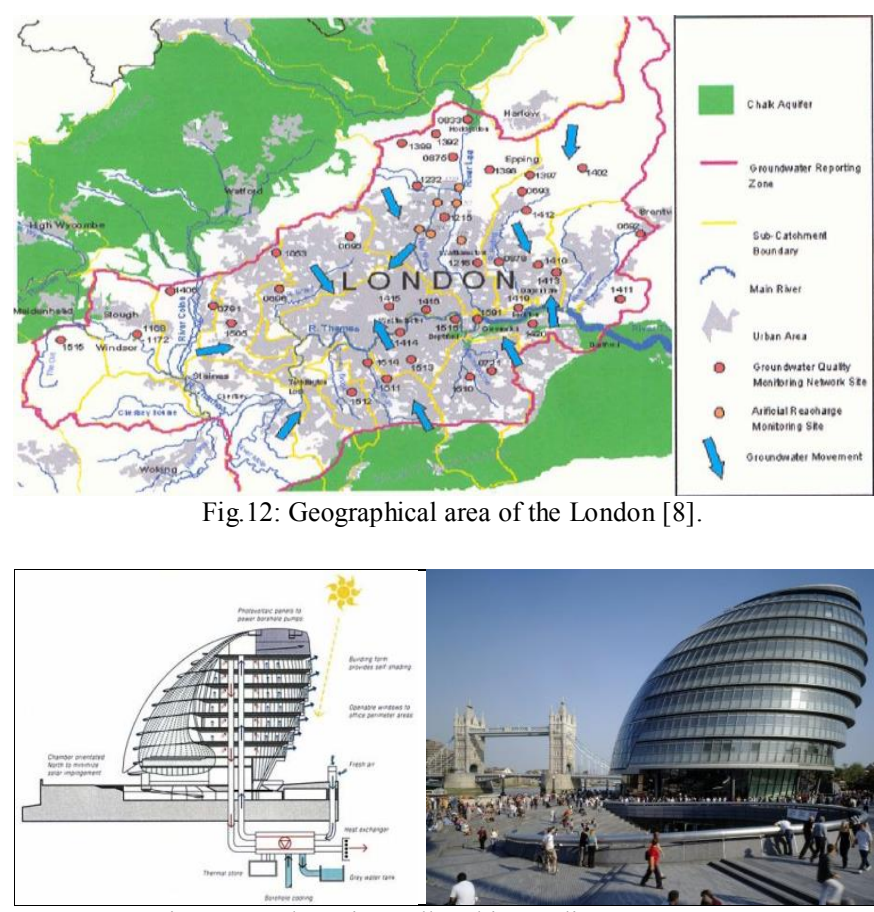

Fig.13: London City Hall and its cooling system [10].

\subsection{Reusing the Basilica Cistern of Istanbul.}

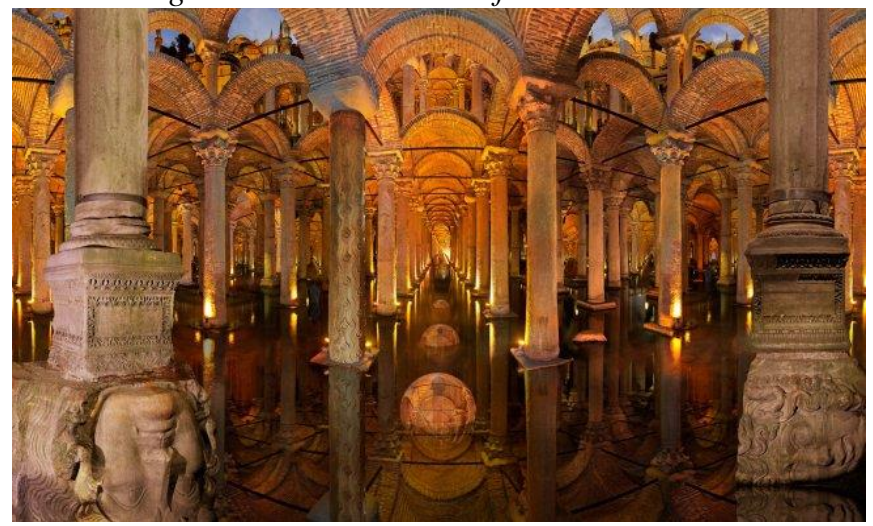

Fig. 14: The interior of the Basilica Cistern, Istanbul [11].

The ancient cistern that runs at the proximity of Hagia Sophia in Istanbul is named after the Stoa Basilica the large public square on the first hill of Constantinople. This subterranean structure was commissioned by Emperor Justinian in $532 \mathrm{AD}$. It is the largest surviving Byzantine cistern in Istanbul; it was constructed using 336 columns, many of which were salvaged from ruined temples and feature fine carved capitals. Each is 9 meters high, arranged in 12 rows of 28 columns each spaced 5 meters apart. It was able to store up to $80,000 \mathrm{cu}$ metres of water $(100,000$ tons of water) delivered via $20 \mathrm{~km}$ of aqueducts from a reservoir near the Black Sea. (Fig. 14)

In 1984, the cistern underwent a major restoration. During this restoration, the floor was cleaned, and the mud disposal exceeded one meter thick. Thus, an original tile base and a marble cut from Medusa's skull were discovered under two columns [11]. After its renovation, it was opened to the public in 1987 by the Istanbul Metropolitan Municipality. (Fig. 15) 


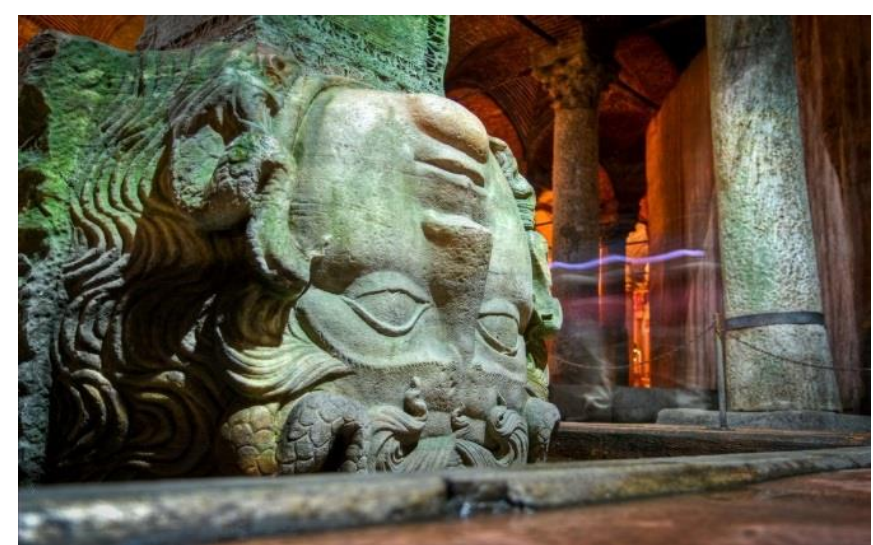

Fig. 15: The marble cut from Medusa's skull which was discovered under two columns during the restoration process [11].

The renovation entailed providing the cistern with enough water to touch the bases of the columns to hint to the visitors for the use of that magnificent space. On-going research has recently discovered a complicated system of water supply and drainage consisted of various channels and wells; attributes which made the visits to that cistern as one of the first touristic destinations in Turkey [12].

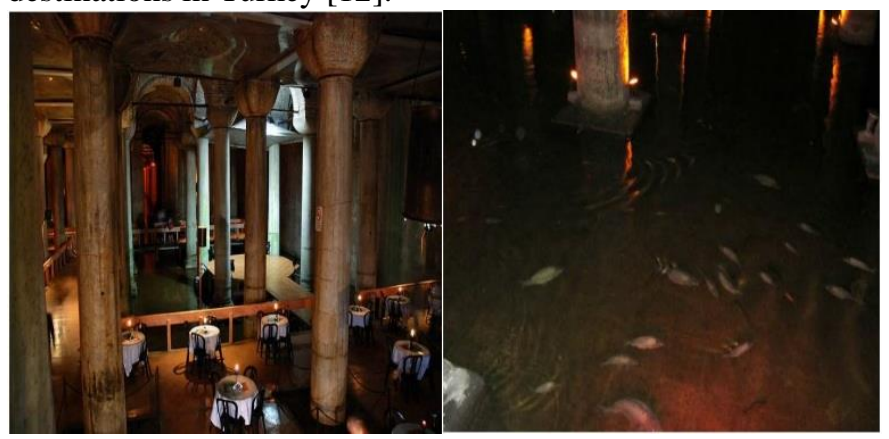

Fig. 16: Reusing the cistern as a restaurant and fish reserve [11].

\subsection{Utrecht restores its water canals}

Utrecht it is an old city that goes back to the medieval time. By the 1950s it had become customary in the Netherlands to fill in unused waterways to make way for motor traffic. The city council, eager to modernize the city, looked at the American cities as an example and thus initiated a proposal to pave over the whole moat, creating a ring road around Utrecht's center. With the Dutch society focused on alternatives to single occupancy vehicle traffic (bikes, walking, public transportation), views on urban traffic have recently changed. The need for high-capacity highways has diminished significantly. In March 2010, the motorway at the bottom of the former moat was closed to all traffic; and in late October 2015 the digging started to formally re-open the canal on the 18th of December 2016. The city is currently considering completing the final stretch of it whose length is about two hundred feet to completely restore its grand moat. The removal of the motorway is perfectly in line with the new Utrecht policies that determine that the main road users in the city are people cycling and walking, not people using private cars [13]. (Figs 17-19)

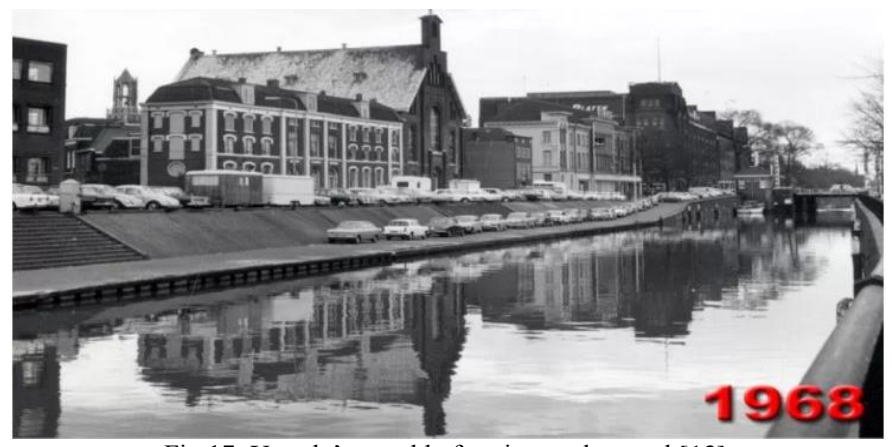

Fig 17: Utrecht's canal before it was dammed [13].

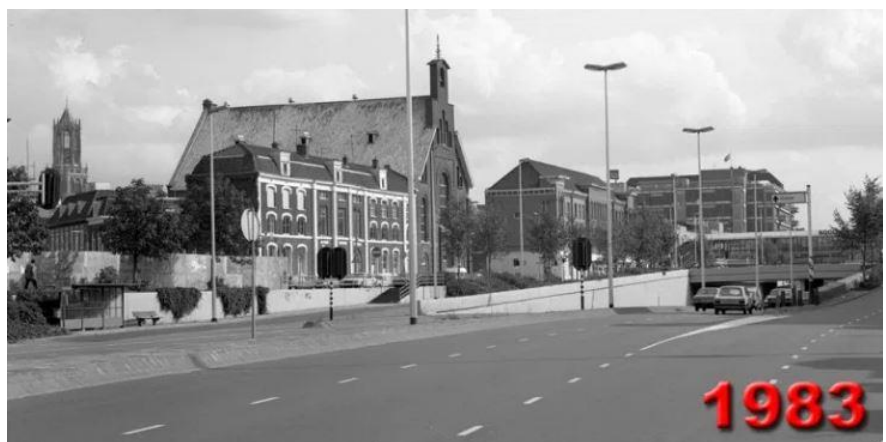

Fig. 18: Utrecht's motorway which located above the dammed canal [13]:

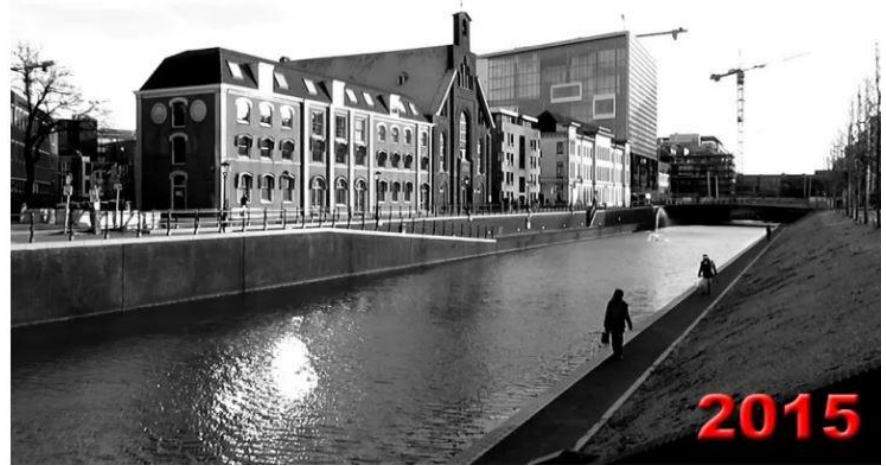

Fig. 19: Utrecht's canal after restoration [13].

\section{SUMMARY AND RECOMMENDATIONS.}

Throughout the international examples, we learn that rising groundwater can, in fact, be considered as an opportunity to achieve different visions. The three approaches that are presented in this paper can be summarized as the following:

1. The use of groundwater to offer environmental control, by integrating the groundwater through cooling systems to control the climatic conditions for the buildings and selected public spaces. (The case of London).

2. The groundwater can be used to Accentuate the historic values of ancient water resources by restoring and reusing some of them (The case of the Basilica Cistern of Istanbul).

3. The groundwater can be used to restore and reformulate water features for the improvement of open public spaces (The case of Utrecht's canal). 
During the $19^{\text {th }}$ century, most of the canals, lakes and ponds of Cairo were filled up possibly with little knowledge about the city's aquifer which has since been accumulating an excess of surface water causing the groundwater to reach to a level that threatens the city's built heritage. This research suggests that in order to tackle that perturbing problem, the groundwater should be treated as being an opportunity to profit from. The three presented European cases offer frameworks in that respect. Historic Cairo's aquifer is similar to the one of London and its groundwater is of a temperature that can be profited from in air conditioning. Similar to Istanbul, Historic Cairo has many underground historic cisterns which were once used as the main water supply to the city. The restoration and the rehabilitation of those cisterns can be an additional heritage attribute from one side, but also means to collect groundwater and make use of it. Finally, and like those of Utrecht, the canals and lakes of Historic Cairo were of such particular environmental and social characteristics that reviving them would restore values besides promoting better groundwater management. This research, therefore, suggests that Cairo would adopt all three approaches. The applicability of each, however, requires a framework and depends on a set of suggested criteria. Below is a summary of such frameworks and dependent criteria; aspects which are being further explored and detailed in a forthcoming research thesis.

\section{Framework No.1:}

The existing underground cisterns in Historic Cairo which lost their related components of water distribution within a historic water establishment, such as al-Sabil or al-Hammam, can be restored and re-used to be the hub to supply the surrounding neighborhood with collected groundwater to be used for climatic control. Those cisterns can be supplied with a simple pump and filtering system that would guarantee that the cistern would constantly be filled up with cool groundwater. It would then be connected with a network of cooling pipes to feed the surrounding buildings with possible outlets for airconditioning climatic control units. Property owners instead of purchasing electrical air-conditioning units would then pay nominal membership fees to connect to the proposed system. The collected fees can go into the maintenance of the used cistern as well as to the system of water collection and distribution.

\section{CRITERIA of the prospective cisterns for framework 1:}

1.1. The selected cistern should be in a central location in relation to a specific neighborhood so that it would act as being its water reservoir.

1.2. The selected cistern should be associated with water establishment of not of a high historic and architectural values, leaving those to potential uses for cultural tourism aspects.

\footnotetext{
* This research is part of an on-going research on the subject, and extracted from a thesis that is scheduled to be defended in the Department of Architectural Engineering, Menoufia University during the year of 2019 .
}

1.3. One selected cistern should serve one neighborhood in order to assure a monotony of the system and to confine the rights and responsibilities of the users towards the cool-water feeding system.

1.4. The selected cistern should be within a public domain under the supervision of the local authority but running and maintained by the local community benefiting from it.

1.5. The selected cistern must have enough space(s) in its vicinity to install the requirement tools and equipment that would assure the new function that would be assigned to it.

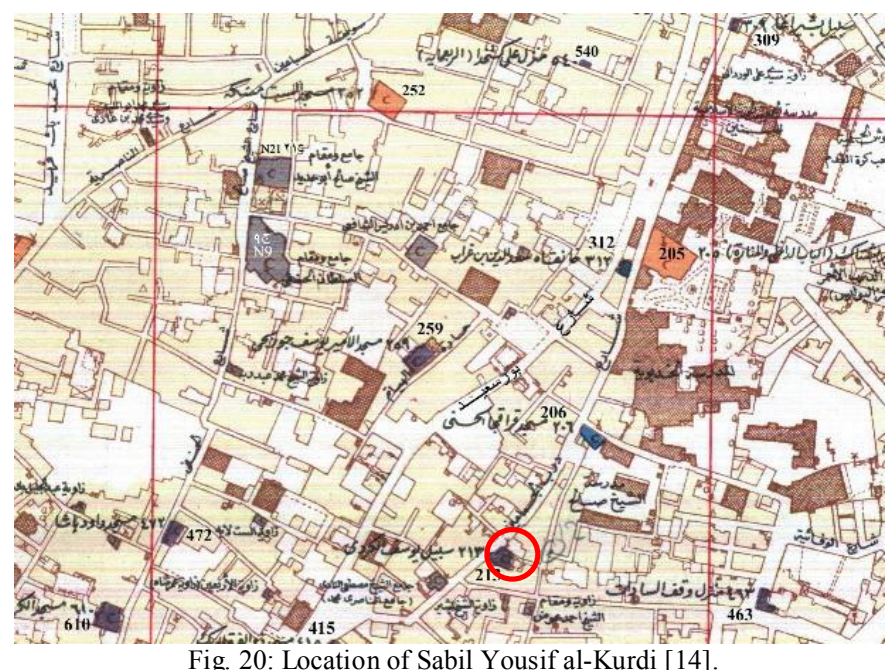

Fig. 20: Location of Sabil Yousif al-Kurdi [14].

The following are potential examples of cisterns that meet the proposed criteria and can be used as the groundwater tank to supply its surrounding neighborhood in Historic Cairo with the cooling water. Sabil Yousif al-Kurdi (monument No. 213) is locating at Darb al-Gamamiz Street, Bab al-Khalq Square, al-Darb al-Ahmar. (Fig. 20). This Sabil has lost one of its main components which is the Kuttab. In addition, the Sabil has been a subject of various restoration works that disfigured many of its authentic historic fabric, namely the original flooring which was replaced with modern tiles, as well as the addition of several modern rooms on a large part of the building to be used for residences. However, the cistern of Sabil al-Kurdi still exists underground. There are many unused rooms in the ground floor, namely the one where the nozzle of the cistern exists, that can be used as a space to install the required tools and equipment required for the suggested neighborhood cooling system [15]. (Figs. 21-22) 


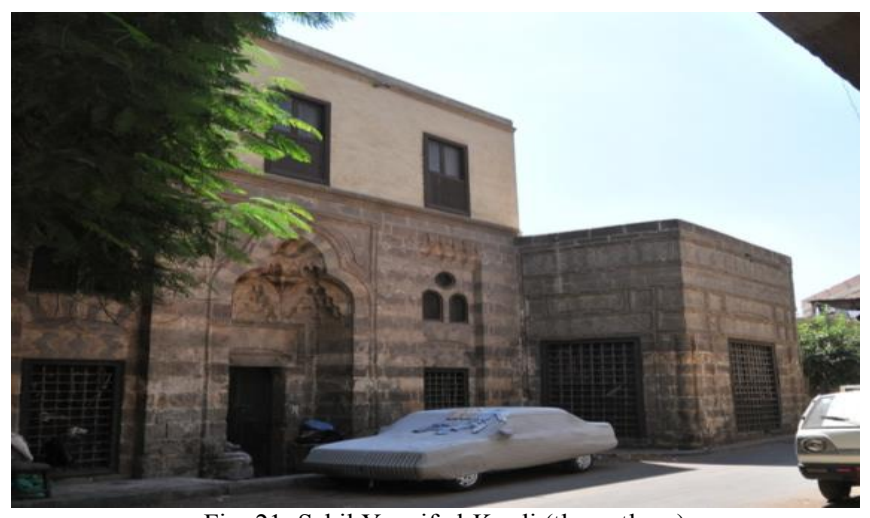

Fig. 21: Sabil Yousif al-Kurdi (the authors).

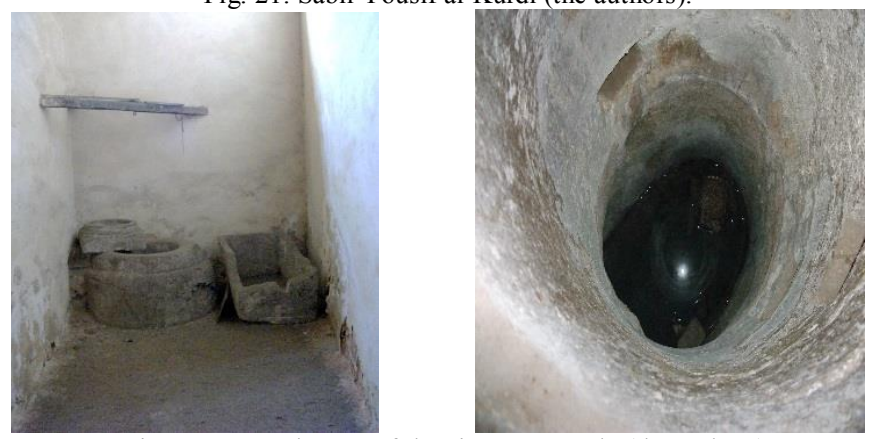

Fig. 22: Unused room of the cistern's nozzle (the authors).

Another potential cistern is the one of Sabil Khesro Basha (monument No. 52) locating at Al-Moez Street in the district of al-Nahassin. The Sabil lost its shazrwan which had been destroyed [15].The cistern, however, still exists but neglected and filled up with accumulated debris and garbage. Its nozzle is in a room that can accommodate the equipment proposed for the cooling water system. (Figs. 23-24)

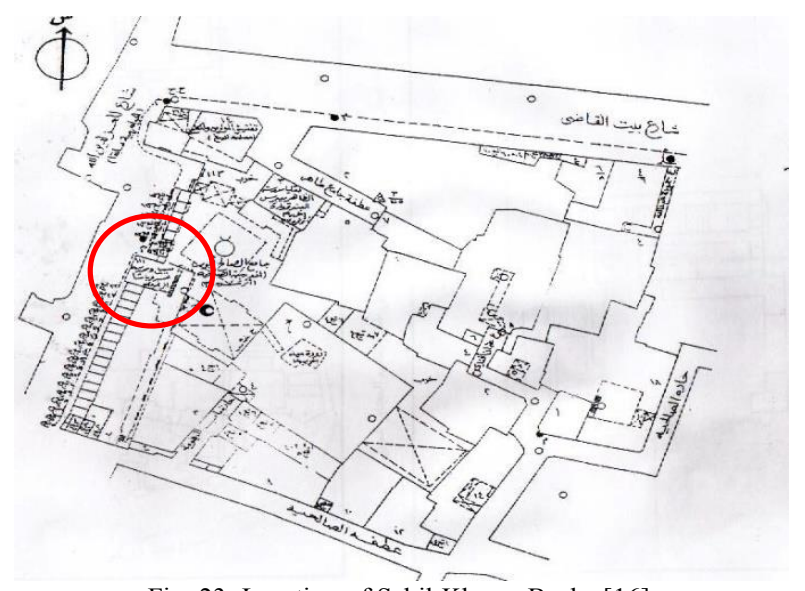

Fig. 23: Location of Sabil Khesro Basha [16].
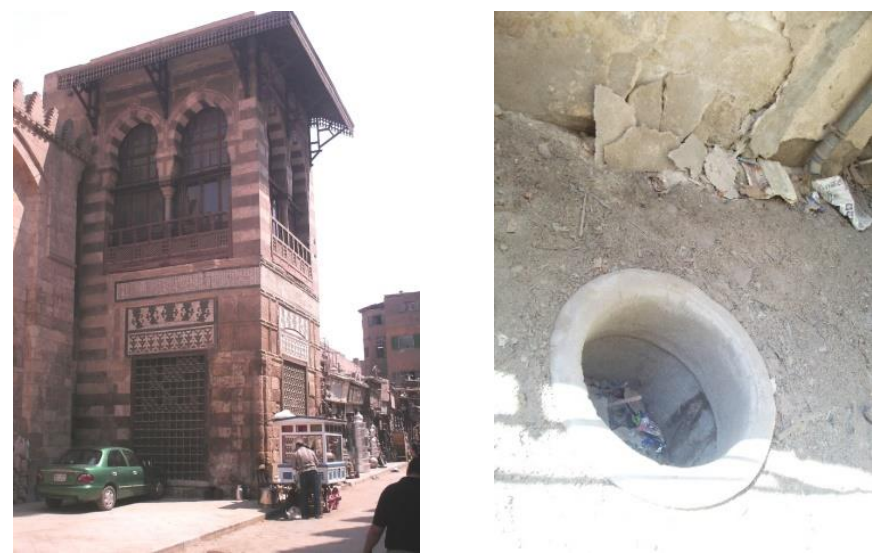

Fig. 24: Sabil Khesro Basha and the nozzle of its cistern (authors). Framework No.2:

Cisterns can be a great potential to accentuate the outstanding values of the city of Cairo and invest them in stimulating cultural tourism activities that would be based on representing the genius water systems of the historic city. In order to achieve that objective, cisterns shall be selected among those which are parts of high-value monuments that function on water resources such as those of Sabils. Those cisterns could be reused to demonstrate to the visitors the systems involved in collecting and distributing the water. This approach will not only support the reuse of a high-value monument but would also demonstrate to the public and tourists how they were traditionally used.

In doing so, it is suggested to reintegrate water into that historic system that would be pumped out from the groundwater after filtering it and making usable for the purpose. Used water can then be used as grey water for sanitary purposes and flushed in the main city sewerage system if the mandate is to lower down the level of the rising groundwater.

\section{CRITERIA of the prospective cisterns for framework 2:}

2.1. Cisterns that exist in high-value monuments that would be of strengths to consider as a touristic attraction.

2.2. Cisterns and their monuments can be integrated into touristic trails to demonstrate the water system of historic Cairo.

2.3. The monuments should have all of its features preserved and well-integrated so that the all the prospective water circulation would be illustrative and well interpreted.

2.4. In the case if the selected monument has lost any of its related water features, it must be restored based on the existing remains. An example of such criteria is the salsabil decorative plaques which were usually removed from the Sabils of Cairo to be exhibited in the Museum of Islamic Art. Replicas in such cases can fulfil the purpose.

Some of the examples of cisterns that are located in value monuments in Historic Cairo and that can be used in the 
second framework suggested in this research is the cistern of the Mosque-Sabil-Kuttab of Sulayman Agha Al-Silahdar (monument No. 604). It is a complex of a mosque, Sabil and Kuttab established during the era of Mohamad 'Ali Pasha. It is located at the beginning of Burjouan alley along the northern section of the famed Al-Moez Street [17]. The Silahdar complex can be suitable for activating the second framework because it really fits the set criteria for it of a high value and well-integrated in a touristic area, and since its Sabil still preserves all of its features in good state of conservation including its cistern. (Figs. 25-26) Moreover, the underground cistern was recently made accessible for tourists to visit through a steel staircase.

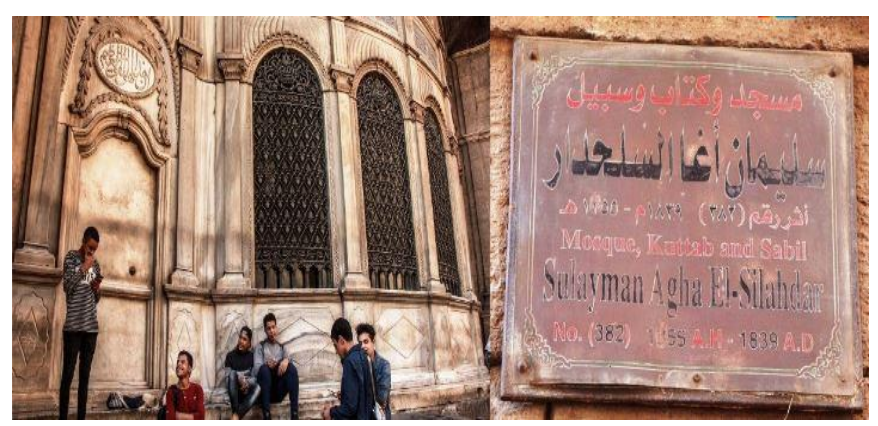

Fig. 25: Mosque-Sabil-Kuttab of Sulayman Agha al-Silahdar [18]

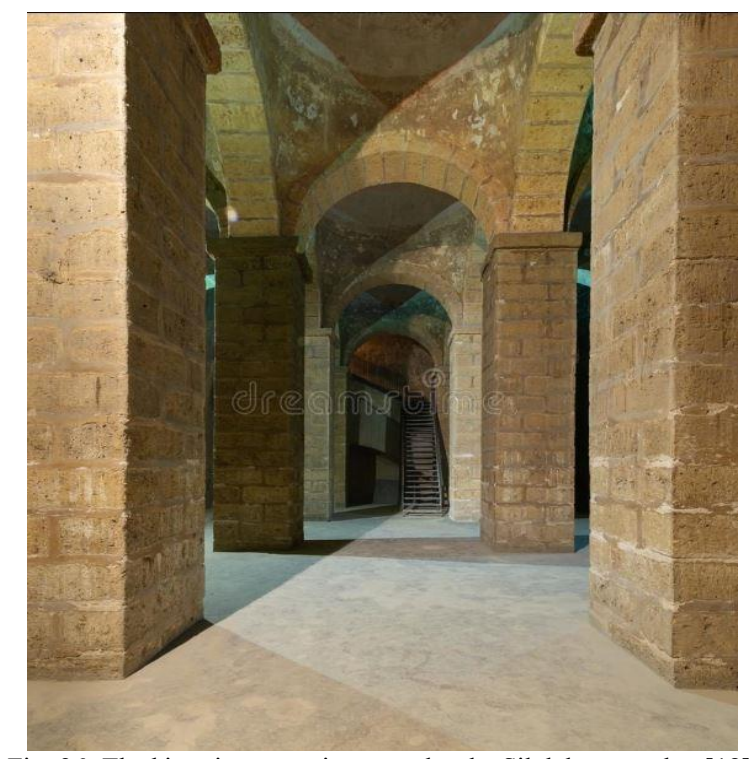

Fig. 26: The historic water cistern under the Silahdar complex [18].

Another potential cistern that can be used within the second framework is the one of Sabil Mohamed Ali in Al-Aqqadin (monument No. 402). Built-in 1820 by Mohamed Ali tributing the death of Toussoun, his young son, the Sabil is one of the most exquisitely decorated in historic Cairo and located on a little piazza along the southern section of al-Moez Street not too far from Bab Zuwayla. Mohamed Ali imported white marble and timber from Turkey, and probably craftsmen as well. He chose to erect a building of such grand scale and splendid appearance as to emphasize its founder's political power. Calligraphic panels on the façade, written in Ottoman
Turkish, display poetic verses and the names of Mahmud II, who was the sultan of the Ottoman Empire, of which Egypt was a part, and Mohamad 'Ali, its governor. The building is restored by the American Research Centre in Egypt with the collaboration of the Supreme Council of Antiquities. It retains its historic appearance and it is open to the public with various exhibitions on the notions of the construction systems in the ground floor as well as for the Kuttab/school in the first floor. As in the case of Al-Silahdar the cistern of Sabil Mohamed 'Ali is accessible via a wooden staircase [19]. (Figs. 27-28)

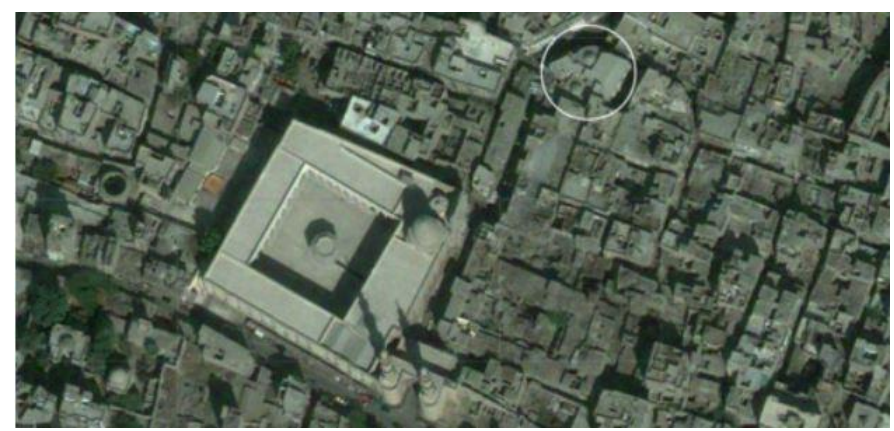

Fig. 26: Location of Sabil/Kuttab Mohamed 'Ali in Al-Aqqadin [19]

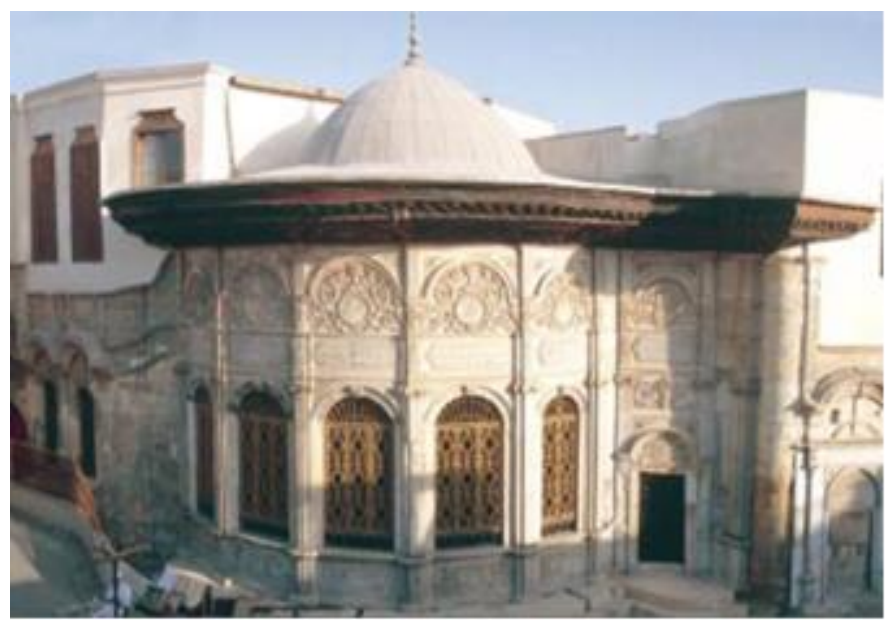

Fig. 27: Sabil Mohamed Ali [19].

Framework No.3:

Like the experience of Utrecht in re-digging and restoring its canals, Historic Cairo can potentially experiment in its vivid and essential water system and selectively restore some of its canals and lakes to retrieve hints of its particular environmental and social characteristics. In doing so, the historic city of Cairo would also profoundly tackle its groundwater problem. The selection of the canals and ponds which can be potentially subjected to the third suggested framework, a set of criteria is proposed.

CRITERIA for prospective canals and lakes for framework 3:

3.1. Canals and/or Ponds shall be selected so that their restoration would enhance apparent degradations in the quality of the open urban spaces. Examples of such cases are the al-Khalij al-Masri Canal in Port Said Street which consists one of the major 
aesthetic problems of the historic city, and a major source of pollution due to the heavy traffic that goes through it. (Figs. 28-29)

3.2. The reintegration process doesn't conflict with functions and built fabric that currently exists. For one example here is the lake of al-Azbakkiyya which is currently replaced with al-Azbakkiyya garden and under which modern metro lines run.
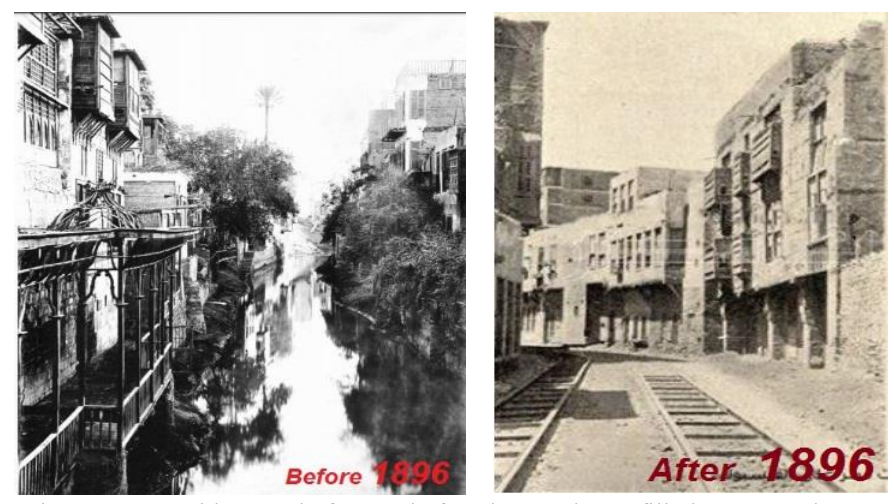

Fig. 28: Port Said Street before and after the canal was filled up [2] and [20].

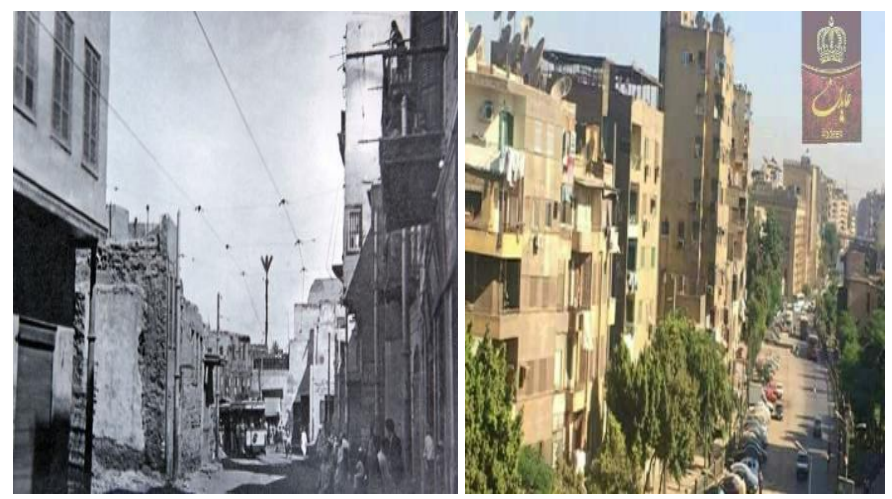

Fig. 29: Port Said Street after filling al-Khalij al-Masri canal [20] and [21].

\subsection{RESEARCH LIMITATIONS}

The research as presented in this paper faces some limitations, many of which will be encountered in the research thesis mentioned above. Some of the limitations which are being currently considered to tackle are as following:

1. The public and local community responses to all of the suggested frameworks, especially the first which requires a high level of the participation of the civil society, are of a concern. The common trend to install electrical air-conditioning systems which are of high electrical consumption shall be challenged to replace them with units based on the circulation of groundwater cold water. A series of public engagement activities shall be designed in order to assure the adoption of such frameworks by the residents, users and visitors of the Historic Cairo.

2. The ability and the suitability of the historic cisterns which are subjects of the first two frameworks are not checked nor assessed, an extensive study on all existing historic cisterns shall be programmed to check such suitability according to the criteria set in this paper.

3. The legal and logistical aspects of the implementation of the suggested frameworks need to be assessed. Responsibilities and rights of each involved stakeholders, whether governmental of members and institutions of the civil society need to be drawn and agreed upon.

4. The suitability of the groundwater temperature and chemical composition in Historic Cairo needs to be assessed. Collaboration of geotechnical and boreholes studies are recommended to explore such suitability, especially in the first framework which requires minimum water temperature and chemical composition that are of no harm to the proposed cooling system.

5. The financial feasibility of the application of the three frameworks shall be assessed and confirm the means on how to appropriate them to implementation without burdens on neither the local government nor the beneficiaries of the output of each framework.

\section{References}

[1] Echols, Stuart and Nassar, Hala, "Canals and lakes of Cairo: Influence of Traditional Water System on the Development of Urban Form," Urban Design International, pp. 204-212, 2006.

[2] Ekmeleddin Ihsanoglu, Ahmed M.Issa, Ibrahim Al-Nawawi and Muhammed Abu al-Amayim, Egypt as Viewed in the 19th Century, Istanbul: IRCICA, 2001.

د. سهير زكي حواس، القاهرة الخديوية، المهندين، القاهرة، مركز [3]

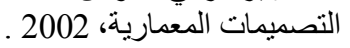

[4] Werner Balderer, Fanny Leuenberger and Hussein Idris, "Origin, Anthropogenic and Climate Influences on the Occurrences of Saline Groundwater at the City of Cairo, Egypt Deduced by Chemical Parameters of the Water Composition", Environmental Earth Sciences, pp. 10-22, 2014.

[5] "Groundwater Foundation", 2018. [Online]. Available: https://www.groundwater.org.

[6] Dr. Kamal Hefny, "Feasibility Study of Water Problems at Coptic Area", Cairo, 1996.

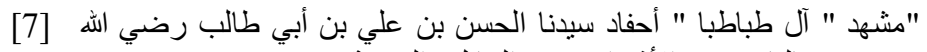

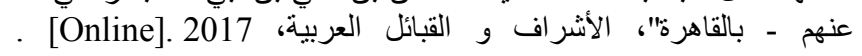
Available: http://www.sada-elarab.com.

[8] F. Ampofo, G.G. Maidment and J.F. Missenden, "Review of Groundwater Cooling Systems in London", Applied Thermal Engineering, pp. 2056-2062, 2006.

[10] "London's city hall: a building's shape maximizing natural solar heating", IIT Building Science Blog, 22/ 9/ 2013,[Online],Available:https://iitbuildingscience.wordpress.com.

[11] Lisa, "In the belly of byzantium: the subterranean spaces of 
Istanbul", 31/ 10/ 2015. [Online]. Available: http://www.thebohemianblog.com.

[12] Ç. Ö. Aygün, "The Wells, Subterranean Passage, Tunnels and Water Systems of Hagia Sophia", ResearchGate, pp. 58-76, 2010.

[13] "Motorway removed to bring back the original water", $2016 . \quad$ [Online]. Available: https://bicycledutch.wordpress.com.

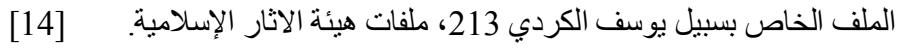

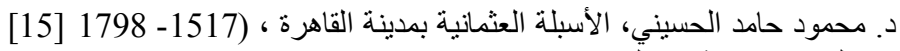

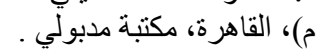

$$
\text { سبيل خسرو بانشان5، مصلحة المساحة، القاهرة . }
$$

[17] A. Doris Behrens, Islamic Architecture in Cairo : An Introduction, Leiden- New York: E.J. Brill, 1989.

[18] "Sulayman Agha al-Silahdar mosque and Sabil-Kuttab," [Online]. Available: https://archnet.org.

[19] "Muhammad Ali's Sabil, 1820", 2011. [Online]. Available: http://cairobserver.com

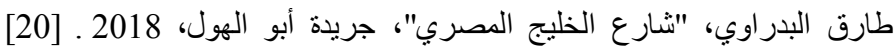
[Online]. Available: http://www.abou-alhool.com.

$$
\begin{array}{r}
\text { [Online]. Available: } 2018 \quad 20 \\
\text { https://www.facebook.com/Amr.Metwly14. }
\end{array}
$$

